\title{
6
}

\section{Americans and Russians as Representatives of 'Us' and 'Them': Contemporary Swedish School History Textbooks and their Portrayals of the Central Characters of the Cold War}

\section{Anders Persson}

\section{Introduction}

Focusing on the textual representation of the two main characters of the Cold War, the USA and the USSR, this chapter presents an analysis of Cold War narratives provided by five contemporary Swedish school history textbooks. The aim is to examine how Americans and Russians are constructed as representatives of 'us' and 'them'. Previous studies on Swedish history textbooks have often focused on the depiction of Sweden and Swedishness (e.g. Danielsson Malmros 2012; Spjut 2014, 2018; Gustafsson 2017), pointing usually to the dominance of nationalist narratives (see e.g. Nordgren 2006; Lozic 2010; Spjut 2014, 2018; Persson 2016) and claiming that most textbook narratives portray an unproblematised 'us'.
A. Persson $(\bowtie)$
Dep. of Humanities and Media Studies, Dalarna University, Falun, Sweden e-mail: ape@du.se 
Focusing on how Swedish textbooks depict Americans and Soviets as particular 'others' (Loftsdóttir 2010; Andersson 2010), I will also examine what kind of general assumptions about historical others inform these portrayals. My analysis will be based on some conceptual distinctions introduced by Hannah Arendt (1982) and Lisa Disch (1994, 1997). The presentation of my empirical results is thus preceded by a short overview of their main ideas, a brief summary of previous studies on the topic, and a general description of the textbooks analysed.

\section{Theoretical Framework}

My theoretical approach draws on the assumption that school history provides an opportunity to promote personal growth by seeking to make use of history as a way of 'visiting' others (Arendt 1982, 1998; Persson 2016). Essentially, this perspective derives from the conviction that history might support young people in their endeavour to be and become the world (Arendt 1998, Persson 2017). This perception highlights an existential potential embedded in history as a school subject (Persson and Thorp 2017; Persson 2017).

History didactics usually refers to the concept of historical empathy when attempting to capture the moral relationship between people in the past and a present user of history (Lévesque 2008). Most often this concept has been employed by representatives of what might be called the tradition of historical thinking, in which historical empathy is normally construed as dependent on individual cognitive capacity. What is emphasised most of the time is thus the need to prevent presentism and the importance of contextualisation, of analytical distance and of scientific procedural competencies (see Blake 1998; Retz 2015).

From an Arendtian perspective, however, such demands, which highlight the necessity to bracket off personal and contemporaneous experience, might be seen as constituting an unfair call for individuals to adopt a comfortable, distanced, touristic view of historical events. From Hannah Arendt's point of view, it is not only such rational distance, but also the opportunity to involve yourself and your own human experiences that must be recognised when conveying narratives about the past (Arendt 1982; Disch 1994, 154). The past is gone; we cannot revive it. However, as 
humans, our being in the world is both constituted by a forgone past and by our present use of history. As present beings we thus exist in a historical and cultural weaving of human relations (Arendt 1998). Following Arendt, the study of history is thus not merely an activity where an isolated subject rationally inspects stories about the past as distanced objects. It is not even sufficient to consider how actors in the past might themselves have been operating with a rational understanding of history. A humanistic desire to recognise the motivation of other people, Arendt argues, requires not only an awareness of the other's disparity; we should also try to recognise ourselves as historical beings (Arendt 1998; ibid., 202-206).

Additionally, using the metaphor of 'go[ing] visiting' (1982, 43), Arendt also asserts the need for imagination when making judgments about other peoples' actions. She thus stresses the obligation we have to construct stories by imagining how we would have experienced and handled a situation similar to that which others have endured (Arendt 1982; Disch 1994, 157; Disch $1997,136)$. In other words, as Disch puts it, 'as a visitor you think your own thoughts but in the place of somebody else' (1994, 159). Consequently, 'visiting' the 'other' does not mean that we can fully embrace others' experiences. If we do not pay attention to the otherness of others, we insensitively make ourselves at home in what should be regarded as someone else's household. Such a naïve attitude derives from the will to assimilate the experiences of another (which is impossible), according to Arendt $(1982,43)$ and Disch (1994, 161-162, 168; 1997, 136). Or, as Disch notes, 'Arendt suggests that there is all the difference in the world between closing your eyes to the world, claiming to see through the eyes of someone else, and attempting to visit see with your own eyes - someone else's position' (Disch 1994, 163).

Drawing on Arendt, Disch $(1994,1997)$ further distinguishes between recognising the circumstances of the other that will create distance, and visiting the perspectives of the other (Disch 1994, 154): 'the work of the imagination when visiting is twofold. It distances me from the familiar and takes me to standpoints that are unfamiliar' (ibid., 160).

Before this backdrop, my analysis of the portrayals of Soviets and Americans in Swedish textbooks will raise three questions: (i) Are the two main characters of the Cold War constructed as possible objects of identification and deprecation? (ii) Do the depictions of their acts and experiences contain elements of recognition? (iii) Are these acts and experiences situated in a way to create a basis for understanding? 
I will proceed in three steps: First, I will investigate how the origin and the development of the Russian and American societies are narrated. Who are they and where do they come from? In what sense do the textbook portrayals of Russians and Americans embrace different kinds of plurality? Second, I will explore the motives ascribed to the two peoples and their leaders: With what intentions are they assumed to act? In what way are their acts situated? Finally I will analyse what judgements are passed in terms of guilt: How, on what basis and from what location, does the textbook retroactively judge the people and the leaders of the USA and the USSR?

\section{Results from a Previous Study}

Sweden is often described as a small nation highly reliant on its international affairs. Until the independence of Finland one hundred years ago, Russia in the east and Denmark in the west have often been attributed great importance in traditional Swedish narratives. Consequently, since the second part of the $19^{\text {th }}$ century it has seemed as if the narrative of a constantly threatened homeland has been rather unopposed in Swedish history textbooks (Persson 2016).

Regarding later post-war events, it seems the portrayal of a peaceful nation trapped between the eastern and western hemispheres correspondingly includes a similar connotation (Danielsson Malmros 2012, 114). Unlike Denmark and Norway, Sweden has never formally been part of the NATO alliance. For some time, the self-image of a third way, a compromise between socialism and capitalism, remained a strong trend in public historical culture (Zander 1998). Nevertheless, previous research on Swedish history textbooks has shown that the depictions of the two superpowers changed notably during the Cold War period. Based on an analysis of almost five hundred textbooks in history, geography, and social sciences published between 1930 and 2004, Holmén (2006) shows that the picture of the Soviet Union was at its most positive right after World War II. During the late 1940s the previous description of the USSR as an undeveloped country was replaced with a much more compassionate description. 


\section{Positive depiction}

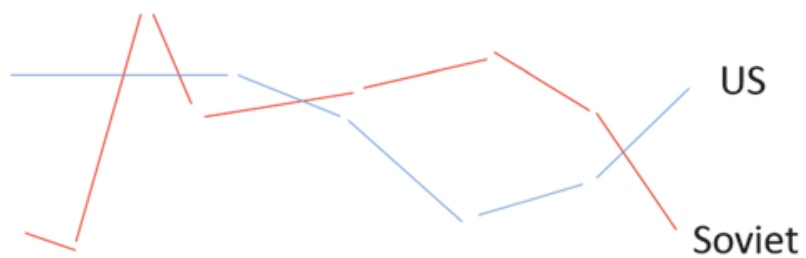

Negative depiction

\begin{tabular}{l|lllllll}
30 's & 40 's & 50 's & 60 's & 70 's & 80 's & 90 's \\
\hline & & & & & & \\
\hline
\end{tabular}

Fig. 6.1 Swedish textbook depictions of the USA and the USSR (Holmén 2006, 237)

However, already in the mid-1950s both political opinion and the textbooks were showing a much more condemning tone against the lack of democracy in the USSR. From Holmén's (2006) perspective, this is mainly explained by a wish to ensure American support during a period when Swedish military capacity was weak. Similarly, he stresses how the reinforcement of the Swedish military force led to the more US-critical approach presented in textbooks of the 1960s. Holmén notes the most anti-American stance, however, in Swedish textbooks of the more radical 1970s. These contain descriptions of social problems and betrayed ideals, and their critique in these narratives appears directed particularly at portrayals of 'underdogs', such as Native Americans and the Vietnamese.

During the 1980s, criticism was directed both towards the USA and the USSR. However, after the collapse of the latter in 1991, distancing from the Russians increased. The Centrally Planned Economy (CPE) system is described as a deficient alternative to the market economy and the undemocratic aspects of the USSR are given a prominent position in narratives published from the 1990s (Holmén 2006).

The present study was carried out more than a decade after Holmén wrote his thesis (2006). In the meantime, both the historical and 
political culture in Sweden and the educational system had undergone a considerable transformation. Far from the previous declaration of non-alignment and neutrality, several Swedish political parties nowadays argue for the necessity of Sweden joining NATO. At the same time, depictions of Russia in the public sphere and in mass media have become increasingly critical.

Simultaneously, since 2011 a major educational reform has been implemented within Swedish compulsory schooling. Regarding history, this policy change particularly includes a more detailed list of content knowledge, more national tests and a more explicit emphasis on disciplinary skills (Persson 2017, 7-11). Source criticism, the use of history, and other disciplinary concepts have thus permeated the new history curriculum. Several Swedish history didactics scholars have described this latter tendency as a striving towards a more academic and analytically distanced approach to history education (e.g. Persson 2017, 18-20).

\section{Textbook Sample}

Unlike many other countries, the Swedish government no longer has any control over the textbooks used in schools. Since 1991, textbook production relies on private companies and the free market. I therefore chose the best-known titles (Utkik 2015; SO.S. 2015; PULS 2009; Levande Historia 2012) from the three largest Swedish publishing houses (Gleerups, Liber and Natur \& Kultur), as well as one textbook from a smaller publishing house, Sanoma: Prio (2016).

As we can see from the following graph, each book comprises between 222 and 390 pages of text, of which between 42 and 99 pages are devoted to the period between 1945 and 1989 or 1991. In all textbooks the majority of the content deals with international relations during this era. In most cases the East-West conflict is given about the same amount of space as North-South tensions during the period in question.

Regarding descriptions of the Cold War as such, the five books examined comprise 17-28 pages. With no exceptions, those pages largely (82100 percent) deal with political and economic aspects of the conflict. 
Table 6.1 Table Showing an Overview of the Main Chronological, Geographical and Content-related Points of Focus in the Four Textbooks under Examination

\begin{tabular}{|c|c|c|c|c|c|}
\hline & $\begin{array}{l}\text { Total } \\
\text { number } \\
\text { of } \\
\text { pages in } \\
\text { text }\end{array}$ & $\begin{array}{l}\text { Pages devoted } \\
\text { to the Cold } \\
\text { War period } \\
\text { (1945-1989/91) } \\
\text { vs. 1989/91- }\end{array}$ & $\begin{array}{l}\text { Pages } \\
\text { devoted to } \\
\text { international } \\
\text { vs. national } \\
\text { (Swedish) } \\
\text { affairs (in } \\
\text { percentage) }\end{array}$ & $\begin{array}{l}\text { Pages } \\
\text { devoted to } \\
\text { East-West } \\
\text { gap vs. } \\
\text { North-South } \\
\text { gap (in } \\
\text { percentage) }\end{array}$ & $\begin{array}{l}\text { Pages } \\
\text { devoted to } \\
\text { politics/ } \\
\text { economy } \\
\text { vs. culture/ } \\
\text { everyday } \\
\text { life (in } \\
\text { percentage) }\end{array}$ \\
\hline PULS 2009 & $345 \mathrm{pp}$. & 56 vs $18 \mathrm{pp}$. & 76 vs $24 \%$ & 31 vs $29 \%$ & 82 vs $18 \%$ \\
\hline Utkik 2015 & $343 \mathrm{pp}$. & 62 vs $17 \mathrm{pp}$. & 66 vs $34 \%$ & 24 vs $6 \%$ & 75 vs $25 \%$ \\
\hline SO.S 2015 & $390 \mathrm{pp}$. & 76 vs $18 \mathrm{pp}$. & 83 vs $17 \%$ & 14 vs $14 \%$ & 95 vs $5 \%$ \\
\hline Prio 2016 & $222 \mathrm{pp}$. & 99 vs $67 \mathrm{pp}$. & 76 vs $24 \%$ & $\begin{array}{l}14 \text { vs } 18 \% \\
25 p p \text { vs } 32 p p\end{array}$ & 76 vs $24 \%$ \\
\hline $\begin{array}{l}\text { Levande } \\
\text { hist. } 2012\end{array}$ & $435 \mathrm{pp}$ & $42 \mathrm{pp}$ vs $9 \mathrm{pp}$ & $80 \%$ vs $20 \%$ & 35 vs $16 \%$ & 79 vs $21 \%$ \\
\hline
\end{tabular}

Table 6.2 Table Showing the Treatment of the Cold War in the Four Textbooks Examined

\begin{tabular}{|c|c|c|c|c|c|}
\hline & $\begin{array}{l}\text { Total } \\
\text { number } \\
\text { of } \\
\text { pages in } \\
\text { text }\end{array}$ & $\begin{array}{l}\text { Pages } \\
\text { devoted } \\
\text { to the } \\
\text { Cold } \\
\text { War as } \\
\text { such }\end{array}$ & $\begin{array}{l}\text { Pages } \\
\text { devoted to } \\
\text { the Cold } \\
\text { War (in } \\
\text { percentage) }\end{array}$ & $\begin{array}{l}\text { Pages dealing } \\
\text { with the Cold } \\
\text { War, devoted to } \\
\text { international vs. } \\
\text { national } \\
\text { (Swedish) affairs }\end{array}$ & $\begin{array}{l}\text { Pages } \\
\text { dealing with } \\
\text { the Cold } \\
\text { War, devoted } \\
\text { to politics/ } \\
\text { economy vs. } \\
\text { culture/ } \\
\text { everyday life }\end{array}$ \\
\hline PULS 2009 & 345 pp. & 25 pp. & $7 \%$ & 64 vs $36 \%$ & 100 vs $0 \%$ \\
\hline Utkik 2015 & 343 pp. & 30 pp. & $8 \%$ & 83 vs $17 \%$ & 90 vs $10 \%$ \\
\hline SO.S 2015 & 392 pp. & $17 \mathrm{pp}$. & $4 \%$ & 88 vs $12 \%$ & 94 vs $6 \%$ \\
\hline Prio 92016 & $222 \mathrm{pp}$ & $28 \mathrm{pp}$. & $13 \%$ & 96 vs $4 \%$ & 82 vs $18 \%$ \\
\hline $\begin{array}{l}\text { Levande } \\
\text { historia } \\
2012\end{array}$ & $435 \mathrm{pp}$ & $18 p p$ & $4 \%$ & 100 vs $0 \%$ & 100 vs $0 \%$ \\
\hline
\end{tabular}




\section{Results}

\section{The Origins of the USSR and the Depiction of the Russian People}

While some differences are visible in the five textbooks examined, the portrayals of the Russian people and the emergence and growth of the USSR as a society show some recurring patterns. The portrayal of the pre-revolutionary years most often begins with a description of the huge gap between the rich and the poor in Tsarist Russia. The injustice is often made clear by a description of the contrast in the living conditions of different social classes, or by noting that most people were hungry despite the fertile lands and abundance of natural resources (SO.S., 246-247; PULS, 192; Levande Historia, 320-324). For example, Levande Historia repeatedly comments on Russian hunger, illiteracy and under-development:

Compared to Germany or France, Russia was undeveloped. Nine out of ten people lived in rural villages and subsisted on agriculture. Three out of four adults were illiterate. Crop failure and famine was common. [...] Together with poultry, cows and pigs, [the Russian peasants] tried to endure the cold of winter, when snow drifted in through thin walls and cold moisture rose from the ground (Levande historia 320). ${ }^{1}$

Although these initial narratives might contain a great deal of sympathy towards starving and oppressed farmers, they also show obvious elements of othering. Instead of intrinsically seeking to grasp their situation, the textbook portrays the serfs as 'malnourished, powerless and desperate' (PULS, 192). ${ }^{2}$ This illustrates a general and frequently used depiction of ordinary Russian people as subdued, cowed and passive. The main exception in this respect can equally be found in Levande historia, which describes starving peasants who, despite everything, turn against 'those who took without giving anything back' (322). ${ }^{3}$ Elsewhere, the only acts of the Russian people mentioned are related to violence. Accordingly, while readers are initially told that soldiers shouted at their officers (Levande historia, 324-325), they also learn that during the Civil War "it was told that "the reds" shot all who had no calluses on 
the palms of their hands' $(P U L S, 197)^{4}$ and that Lenin himself 'let his soldiers march into parliament to close it by force' (SO.S., 248-249). ${ }^{5}$

The lack of narratives detailing positive motives for the creation of the USSR is also conspicuous when we consider how the birth and emergence of the USSR as a society is portrayed in Swedish textbooks. The few Bolsheviks are described as unwanted. Yet people are also commonly described as incapable of preventing this minority from seizing power. Madness and terror ensue (Levande historia, 323-327; SO.S., 246-249; PULS, 194-195). In this book the frequency of words and phrases like 'rotting food', 'cold', 'starvation', 'strikes and demonstrations' is high (323-324). The foundation of the USSR as a state is generally described as a project of malicious leaders in a mix of determination and chaos. The origins of the USSR are thus mired in terror, murder, intolerance and backwardness by the authors of these texts.

Similar patterns shape the depiction of the Stalinist era. In PULS Stalin is described as 'a pathologically suspicious' and 'wary ruler' $(201)^{6}$, comparable only to Hitler and Mao. Yet even though he is obviously unpopular, Stalin is able to seize power 'after a series of ugly tricks' (PULS, 199)..$^{7}$ The story of Stalin's rise to power is thus similar to that of the supposedly unwanted Bolsheviks. The Russian people do nothing to stop it; rather, as in Utkik, the reader learns of dying farmers, detention camps, executions, famine, raids and horror (218-219). Instead of describing the active resistance of the peasants, the narrative notes that anyone who refused to co-operate would find him- or herself in trouble (SO.S., 259). The only notable exception in this respect seems to be the inclusion of the fact that some peasants, despite everything, resisted the Soviet central power by slaughtering their livestock and destroying their tools (Levande historia, 329; PULS, 199).

In some cases the passivity of the Russian people is related to the Soviet system as such. Comparing the USSR to Nazi Germany, some of the textbooks claim, for instance, that the Soviet communists 'wanted to make every man think in a new way. Anyone who did not fully support the party would be seen as an enemy without the right to live' (SO.S., 257). ${ }^{8}$ The Russian people are once again described primarily as powerless and oppressed sufferers. People suffered from the cold in dark apartments (Levande historia, 329), starving and dying in tens of millions, and yet only seldom seem to resist. Rather, the Russian people are said to 
be afraid (Utkik, 219) and forced to betray their friends and family (SO.S., 260). ' The most detailed descriptions of Stalin's reign of terror can be found in Levande historia, which devotes a large amount of space to describing life in the prison camps of the Gulag:

In the camps political prisoners were incarcerated together with criminals. Prisoners could be raped, murdered, forced to work themselves to death, or die from hunger or disease. It took strength, skill and luck to survive. [...] The feeling that no one, absolutely no one, was safe created enormous suspicion and fear that permeated all of society. Anyone could be a spy. It was easy to turn in someone you did not like, a neighbour whose room you wanted - many families were forced to share apartments - a rival, or a girl who refused to have sex (Levande historia, 331). ${ }^{10}$

However, the lack of opposition on the part of the Russian people is not only explained by the climate of fear. Even if both Chrustjev and Gorbachev are described as reformists in some ways (PULS, 305-307; Utkik, 266; SO.S., 376-377; Prio, 76, 187; Levande historia, 383, 389, 393-392), the inefficiency and bureaucracy of the communist system, these textbooks repeatedly claim, served to pacify its citizens:

The Soviet Union could manufacture nuclear weapons that threatened the whole world, but not enough food, clothes and homes for their own people. There were plenty of natural resources in the Soviet Union: gold, oil, coal, iron and much more. Communists exploited nature to access these riches. Then they could afford to equip the world's strongest army. But large parts of the country were poisoned by environmental degradation (SO.S., 374). ${ }^{11}$

In PULS (306) ${ }^{12}$ it is noted that 'no one dared or wanted to take individual initiative'. Furthermore, in the textbooks stressing the environmental pollution, corruption and the inefficient and impassive system in the USSR, the citizens are often portrayed as unreceptive collaborators. In SO.S., the ordinary people are even implicitly described as drunkards and thieves:

The new leaders who came to power in the 1950s and 1960s decided that more food, clothes, homes, cars and televisions would be produced, which people needed. Then one of the Soviet Union's major weaknesses was 
exposed: ordinary people were forbidden to own businesses and try to become wealthy. In the Soviet Union, it was the state that owned all companies. And it did not matter if a company went badly, the state paid the workers' wages anyway. Therefore, many employees did not feel they needed to make an effort. It was common for people to get drunk at work, or not go there at all. When the state owned the companies there were many who did not feel responsible. People stole goods and sold them. The factories and agriculture became worse the more time passed. [...] Those who dared to complain were sentenced to punishment or locked away in mental hospitals. But those who worked for the party did well. They could travel abroad, and shop in special stores with foreign goods. There you could find all the things that ordinary people lacked (SO.S., 112). ${ }^{13}$

This allusion to Russian consumption is no exception. Utkik is the only textbook which does not mention this. PULS claims that the peasants' savings were 'often [...] spent on vodka' (192) ${ }^{14}$ and that 'humour and vodka were the people's only consolation' (306). ${ }^{15}$ Beyond stressing that Russians often drank at work, SO.S. also claims that in the shops there was almost nothing to buy except vodka' $(S O . S ., 11) .{ }^{16}$ While the narratives on the USA and Western Europe include prominent cultural figures, inventors and industrialists, virtually none of their Soviet counterparts appear in narratives on the USSR. Not only the Soviet system but also the overall picture of the Russians thus becomes distanced.

The portrayal of the Russians' miserable existence is only challenged in Utkik, in which descriptions of ordinary Russian people are consistently more varied. Describing Russia during the revolution, the narrative states how hungry, poor and war-weary people were actively united in the rebellion against the rich. Furthermore, this textbook is the only one to remind us that, one hundred years ago, Russia already had electricity, trams, schools and cinemas (Utkik, 209-10). Elsewhere, however, we are presented with a truncated portrayal of an unattractive political and economic system and a people apparently incapable of understanding their own agency. Or, as claimed under the headline 'Communism: Threat or Liberation?' in PULS (284), these textbooks argue that people in the East 'had never learned about democracy'. ${ }^{17}$ It was due to this lack of knowledge, it is claimed, that the people tolerated the lack of freedom imposed upon them by the communist system. 


\section{Soviet Leaders' Motives during the Cold War}

If only reconsidering the outbreak of the conflict, most of the textbooks analysed describe the Soviet leaders as playing the most active and aggressive part (Prio, 63-66; PULS, 285; Utkik, 256; SO.S., 337), blaming them for their support of communist dictatorships in the whole of Eastern Europe. Only Levande historia (377) explicitly mentions that certain acts of the USSR were motivated by fear of new aggression from the West and an interest in creating a buffer zone for protection. Still, the same textbook contains phrasing that signals Soviet malice and aggression:

In 1948 the USSR blocked the Western allies' zones of Berlin in an attempt to starve them and seize power. The Western allies - the USA, Great Britain and France - responded by having a stream of aeroplanes, an aerial bridge, fly in groceries and other goods. Stalin had to comply and the blockade ended after eleven months. The relationship between the USSR and the USA was at a record low. The American journalist Walter Lippman made the conflict known as the Cold War (Levande historia, 378). ${ }^{18}$

In some cases the textbooks seem to argue that it was the Soviet desire for expansion that led to the Cold War. One textbook even claims that 'Stalin wanted to turn the Soviet Union into the world's strongest country' (SO.S., 258). ${ }^{19}$ Most authors of these textbooks consider it important to include the consequences of these ambitions for other people. For instance, PULS (284) states: 'After 1948, almost all of Eastern Europe was ruled from Moscow. [...] The borders were strictly guarded. Those who tried to escape were shot or locked up in prison' ${ }^{20}$ Although the textbook touches upon Eastern European resistance in 1989, these textbooks generally contain very few stories of resistance by Soviet citizens.

\section{The Judgement of the USSR during the Cold War}

When it comes to blame for the Cold War, the textbooks analysed varied somewhat with the different phases of the conflict. Portrayals of the 1960 s often include a positive approach to the USA's actions internationally, arguing that the USA acted in response to Soviet aggression. In Utkik 
we learn how the USSR was forced to make great sacrifices during World War II, while the USA was not (254). Still the textbook argues that the policies of the USSR in Eastern Europe marked the beginning of the conflict: 'The Cold War began when the USSR introduced communism in Eastern Europe' (254). ${ }^{21}$

The USSR is typically described as playing the most active role, thus appearing as the guilty party when it comes to the escalation of the conflict (PULS, 286, 288-289; Prio, 63-66; Levande Historia, 378; Utkik, 253-256). In most of these cases, the Berlin blockade is typically presented as the single event that increased tensions between East and West. The textbooks also emphasise how the Soviet government made use of other countries in Eastern Europe, implicitly suggesting that it was greed driving its actions. While the American Marshall Aid Program is presented as a welcome contribution of supplies and economic support in the West, the reparations that the Soviets demanded from their European neighbours are portrayed as an extensive outflow of goods from Eastern Europe to the USSR (PULS, 286-287; Prio, 64-66; Levande Historia, 380, SO.S., 304-305).

The textbooks level heavy criticism at the USSR for its actions in Eastern Europe. Levande historia states that Eastern Bloc leaders built the Berlin Wall in order to prevent people seeking freedom, and that they also, without any apparent explanation, built threatening rocket bases on Cuba (383-384). In many cases we are told how the people of Eastern Europe, despite their 'isolation', knew that their counterparts in Western democracies were much better off and in some cases tried to protest against Soviet oppression (PULS, 288-89; Utkik, 257; SO.S., 178; Prio, 76). These aspirations came to nothing; instead we learn how Soviet tanks repeatedly quashed the 'Eastern European people's hopes for freedom' (SO.S., 178). ${ }^{22}$

This moral judgement of the USSR is also prominent in the textbook portrayals of what finally happened in Eastern Europe in 1989. SO.S., states that this was the year of freedom and democratic revolution for Eastern Europe $^{23}$ (SO.S., 378), and in PULS (310) we are told how statues of Lenin, Stalin and other despised dictators in Eastern Europe were torn down. However, many of the textbooks omit the collapse of the USSR (PULS, 307; Prio, 78-83; Levande Historia, 391-39; Utkik, 276- 
278). On the phenomenon that countries like Bulgaria and Albania soon re-elected communist leaders, the textbook explains: 'the communist politicians managed to retain power because there were not enough people in these countries who knew how democracy really worked' (SO.S., 379). ${ }^{24}$

\section{The Origins of the USA and the American People}

The textbooks portrayals of the birth and progress of the USA as a nation and the Americans as a people are much more complex than those of the USSR and the Russians. However, the description of the conditions of Native Americans is worrying; they are continually referred to as 'indianer' (Indians), and descriptions of African-American history and people are equally concerning (Levande Historia, 276-277; Utkik, 122123; SO.S., 228-234). In PULS, it is explicitly mentioned that the Europeans took the land from people that already 'had' it (203), and the treatment of the Native Americans is even associated with ethnic cleansing (208).

In addition, however, the narrative of the birth and rise of the USA within these textbooks is (with the exception of the more particular narrative in Utkik) mainly one of freedom, progress and success (SO.S., 228, 235-236; PULS, 205-206, 211-212; Levande historia, 202-203, 278281). In several cases this achievement is often attributed to European immigrants. In contrast to Russians, Americans are frequently depicted as a people of innovative and diligent entrepreneurs. There are numerous examples of young, creative and strong people who are prepared to work hard (PULS, 206, 211; Levande historia, 267-269). Under the headline 'The USA became a superpower' one textbook explicitly claims that it was skilful young immigrants who made the economic success of the American nation possible (PULS, 209). In several cases comparisons are also explicitly made with Karl-Oskar and Kristina, two (heroic) protagonists of a well-known Swedish novel about emigration to the USA (e.g., PULS, 206; Utkik, 180). In PULS it is claimed, for instance, that European immigrants 'often were farmers, poor but hard working, like Karl-Oskar and Kristina' (206). ${ }^{25}$ 
Furthermore, the USA is depicted as the country of opportunity. It is said to offer most of its immigrants the right to vote, as well as religious freedom and a chance to earn much higher wages (PULS, 211-212; Utkik, 180-181; SO.S., 215-217). Almost nothing, however, is mentioned about the individuals who failed or struggled to survive. Equally, the association these textbooks make between the American people and freedom extends to the creation of the nation as well. The struggle against Britain is referred to as a war of freedom. Levande historia even claims that the various states unanimously begged to become a part of the new attractive union (271). Similarly, Utkik mentions the right to life, freedom and the pursuit of happiness as the foundation of the newly liberated nation (121). While the origin of the USSR is mainly associated with chaos, violence and oppression in the textbooks analysed, the birth of the USA is related to freedom and the Declaration of Independence and Human Rights. For instance, beneath the headline 'How the USA was born', the authors of PULS explain the origin of the country by referring back to the Declaration of 1776 . With references to its claims that 'all people are created equal', 'all power is based on the people' and that 'all laws must be approved by the people's representatives' (PULS, 205) ${ }^{26}$, this text explains that the USA came to be regarded as the land of freedom on earth (for white people). In SO.S. the USA is even claimed to be the most democratic country in the world (227).

Likewise, when portraying the events of the early twentieth century, the narrative of economic and industrial success is highly prominent in these textbooks. Levande historia even argues that it was the absence of tollgates and taxes that caused an increased production of both agricultural and industrial goods: 'The United States became the country where the factories produced the most goods in the world. Lots of people found work and earned good money' $(278-281) .^{27}$

Accordingly and in most cases, descriptions of the Civil War and the roles of the North and the South in the conflict appear as unfortunate parentheses in the main success story. Here too, however, Utkik offers a more multifaceted description. It not only states that some loyalists were against the idea of the USA; it also ascertains that women, the poor, slaves and natives were not allowed to vote (Utkik, 122-123). This textbook is the only one to accentuate how the Civil War claimed more victims than 
all other wars in which the USA has participated since. Furthermore, the authors mention that the gap between the North and South remains visible today (Utkik, 161-162; PULS, 210). Utkik is also unique in the sense that it is the only textbook to deliver criticism: It asks whether the USA was really 'a country of the future' for everyone? $(167)^{28}$ or 'did everyone in the United States enjoy the "roaring twenties"?' (229). ${ }^{29}$

The other textbooks, however, seem to express a deep admiration for what the Americans achieved before the beginning of the Cold War. While these texts do not mention Russian or Soviet culture, there are frequent mentions of American jazz music, Hollywood (in one case described as the 'Factory of Dreams'), Walt Disney, Mickey Mouse, Donald Duck, Charlie Chaplin, and Duke Ellington (e.g., PULS, 213-214; SO.S., 234). Furthermore, the text presents the success story of American industry during the early twentieth century, with electricity, cars, vacuum cleaners, radio and electric stoves (PULS, 213-214; Utkik, 215; SO.S., 254). PULS uses the heading 'The land of the future' when it highlights the inventor and 'genius' Thomas Edison (211). Thanks to him, students learn, we now have both the light bulb and the steam power plant. Henry Ford is not only mentioned in relation to the invention of the assembly line principle; he is also associated with increased worker salaries (SO.S., 236). Furthermore, these texts also show how - in the aftermath of the catastrophic stock market crash of 1929 - the American president cared for his people by introducing the New Deal (SO.S., 255-256).

In contrast, the narrative of post-war USA is generally more complex. Here the majority of the textbooks expose social issues such as subversive youth culture, racism, and the Civil Rights Movement. In the narratives of the 1960s, the economic gap between American citizens is described as a problem (PULS, 216, 298-304; Levande historia 418-425, 232-234; SO.S., 311-316; Prio, 72-75). Three of the textbooks mention McCarthyist policies against left-wing opponents (PULS, 298-302; Prio, 70; Levande Historia, 424), one book even describing McCarthyism as 'a hysterical witch hunt' (298). ${ }^{30}$ Doubts are raised regarding democracy in the USA, claiming that the rich and their lobby organisations always sponsor the elected president (PULS, 304).

Unlike the critique of the Soviet system, criticism of the USA in the post-war period is mitigated by examples of how the American people chose to fight social injustices and problems. The Civil Rights Movement, 
the Vietnam Movement, the Green Environmental Movement, the Youth Movement and the Women's Liberation Movement are all invoked to exemplify this. The American people are thus ascribed agency and American society is described as something in which citizens can take an active part, bringing about change (e.g., Utkik, 273-274; SO.S., 311314; PULS, 301; Prio, 72, 75; Levande historia, 418-425).

\section{USA Leaders' Motives during the Cold War}

American policy is described in comparatively benevolent terms. Once again, Utkik offers the most detailed description, fostering identification with the individuals affected, such as its portrayal of the benefits of the Marshall Plan with a short story about a young German boy named Dieter and his struggle to survive after the Second World War (253). The Marshall Plan is described as the starting point for the rebuilding of Western Europe. And in SO.S. we read that 'from the ruins of the war, a new Western Europe emerged, richer than ever' (304). ${ }^{31}$

However, the motives of the Americans during the Cold War are not only depicted in terms of magnanimous generosity:

In 1947, the United States government came up with an aid programme for war-torn Europe. The so-called Marshall Aid meant that Western European countries received almost $\$ 13$ billion from the United States. The Americans wanted to bolster the European economy so that Europeans could afford to buy items from the United States. In addition, the Americans were afraid that poverty would encourage Western Europeans to vote for communist parties (SO.S., 304). ${ }^{32}$

If the USSR is allegedly driven by a mad leader and an ideological determination to expand, the USA is generally associated with two other motives. Firstly, its motives are often related to a wish to prevent the expansion of communism in the world. Levande Historia specifies that it was Mao's victory in China in 1949 that originally motivated Truman to establish his well-known doctrine (377-378).

More often, however, American intervention into world politics is related to economic motives, a pattern already visible in explanations as to why the USA entered the First World War. While described as securing 
the victory of France and Great Britain and making 'the world safe for democracy' $(E P O K, 224)$, the book $E P O K$ also suggests that the 'real reason' is to be found in American concerns for export income (226). Likewise, Levande historia claims that the USA entered the war in order to guarantee future payments from European credit holders (311).

Economic motives seem to be even more explicitly articulated in the later sections of the textbook, describing later periods. PULS, for instance, argues that American 'economic interests are more important than the defence of the ideological ideals of democracy' (329). ${ }^{33}$ Similarly, Utkik maintains that it was the defence of the free market and of American domestic corporations that dictated the international agenda of the USA during the Cold War (254).

This kind of reasoning appears most frequently where the textbooks discuss occasions on which the USA have interfered in less developed countries. Utkik claims that economic motives drove the USA to oppose development in Cuba after Castro's rise to power (267), and SO.S. describes Americans as 'worried' following Castro's success, primarily in the light of the interests of American corporations; attempts to overthrow Castro's regime thus ensued (SO.S., 359). Similarly, the textbook authors explain American interference in South America with the note that 'big American companies own a lot in South America' (SO.S., 365). ${ }^{34}$ In some cases the textbooks explicitly state that the USA supported not only non-socialist but also non-democratic regimes: 'In country after country power was seized by USA-supported military regimes' (SO.S., 365). ${ }^{35}$ PULS even states that the American leaders regarded Latin America as its 'dairy cow' (329). ${ }^{36}$

\section{Judgements of the USA during the Cold War}

The textbooks portray the USA as a more-or-less reluctant participant in the Cold War, mostly describing American action around the beginning of the conflict as reactive in the sense that they felt compelled to act upon Soviet aggression (PULS, 216; SO.S., 281; Levande historia, 358). Not even when the textbooks treat the aftermath of the American intervention and deployment of the nuclear bomb in Japan do we sense any critique in the narrative. The traditional narrative of how the nuclear bombs, 
despite everything, saved lives is prominent in the majority of the textbooks. Levande historia, for instance, describes the situation thus:

On 6th August, US planes released a nuclear bomb over the Japanese city of Hiroshima. 80,000 were killed immediately, 70,000 were injured, and the entire city was turned into ashes. Three days later, an atomic bomb was also released over Nagasaki City. This was the only time that nuclear bombs have been used in warfare. Japan surrendered. World War II was over (Levande historia, 365). ${ }^{37}$

In SO.S. the authors even, more or less explicitly, blame Japanese suicide pilots, the latter having forced the Americans to deploy the nuclear bomb (SO.S., 283). Otherwise, the event is described in an equally laconic and declarative manner as in the example above:

At a quarter to nine on the morning of 6th August, 1945, the first atomic bomb was released over the Japanese city of Hiroshima. Three days later, an even more powerful bomb was released over Nagasaki. In only a few minutes 80,000 people died. The next day, Japan was ready to give up. World War II was over (SO.S., 283).

When dealing with later phases of the Cold War, most textbooks take a more critical stance towards American international policies. The American involvement in Vietnam receives the most negative portrayal. According to PULS, the USA tried to diminish 'the influence of the Soviet Union in the world' and therefore intervened in Vietnam (293). In a way similar to how the American treatment of Native Americans is described, the textbooks explicitly take sides with the Vietnamese. It is claimed that the war in South-East Asia cost the USA its hero status and popularity among young people throughout the world (PULS, 292-294; Levande historia, 386; Prio, 71-73; SO.S., 311, 340-342; Utkik, 270273). The Vietnam War 'destroyed the good reputation of the USA in the world' and made the American people realise that they had 'gone bad' (SO.S., 342). ${ }^{38}$ Similarly, Utkik (270) depicts how the USA cancelled democratic elections in South Vietnam and dropped more than three times as many bombs as they released during the whole of World War 
II. We are told of napalm and 2.5 million casualties. The textbook also states how Americans committed atrocities against civilians and 'sometimes burned hamlets randomly' (Utkik, 271). ${ }^{39}$ In SO.S. we are told that American fire bombs destroyed Vietnamese peasant villages, resulting in violent protests in the USA (SO.S., 342): 'For many, the United States' war in Vietnam became a symbol of how the rich world tried to crush a poor people that only wanted to live independently' (SO.S., 311). ${ }^{40}$

As has been noted above, most of the textbooks also devote a great deal of attention to the domestic problems of the USA. The treatment of African Americans, the large economic injustices, and the recession of the 1970 s are often described in a critical manner (e.g. PULS, 216; 298-304; Levande historia, 418-425; 232-234; SO.S. 311-316; Prio, 72-75). The struggle of the African-American community is given most space in Levande historia. Here six pages are devoted to describing Rosa Parks and the bus boycott of Alabama in 1955, the murder of Emmet Till, the church burnings in Montgomery, the brutal police attack against the peaceful demonstration in Birmingham of 1963 and the murder of Medger Evers later in the same year (418-423). In many cases this is contrasted with a more positive development of the domestic situation in the USA from the 1980s onwards. PULS tells us that 'the American economy improved' and that African Americans were able to prosper and 'work their way up in society'. ${ }^{41}$

\section{Discussion}

The purpose of this article has been to examine how Swedish textbooks construe Americans and Russians as representatives of 'us' and 'them'. The results that this study has yielded unveil insight as to how Russians and Americans are framed as objects of identification. By taking as my point of departure Lisa Disch's conceptualisation of Hannah Arendt's call to 'pay a visit', I furthermore intend to discuss how these two actors are textually treated as representatives of 'us and 'them'. In what respect do the depictions contain elements of recognition, and to what extent do they express the will to situate and understand the acts and experiences of these two historical players? 
Regarding the portrayals of the Russian people and the Soviet Union, it seems reasonable to claim that readers of these Swedish history textbooks are offered limited opportunities to 'pay visits' in the Arendtian sense. To begin with, the character of the Russian people is repeatedly described as inexplicably passive. Most things seem to 'just happen'. No one likes the Bolsheviks, and no one wants Stalin in power, yet these entities seize power nevertheless. The situation appears terrifying and chaotic, but still the Russian people do not take action. Instead they are described as rendered passive and oppressed by the system.

Another problematic aspect is that the Russian people often appear as a homogeneous group. A great deal of what is said about the Russian person as a human being is therefore foreign and odd. Russians are described as people who are drunk at work, seeking solace in vodka. Their actions often seem motivated by malevolence and betrayal. In one case, Swedish textbook readers learn that a Russian man who was denied sex by a girl could take revenge by turning her in to the Secret Police.

Portrayals of Americans and of the USA appear to be strikingly different. Although there are also narratives of terrible oppression of Native Americans and African Americans, we also repeatedly hear stories about active, young and industrious immigrants. By references to famous brands such as Ford and Disney, well-known cultural figures such as Chaplin and Mickey Mouse, and great inventions such as the light bulb and the automobile, there should be opportunities for recognition on the part of the readers.

Furthermore, there are variations in how critical elements in the history of the USA and the USSR are presented in the textbooks studied. While an explicitly critical stance is taken in regard to the American atrocities towards African-American citizens and civilian Vietnamese, these are also connected to portrayals of how other Americans protest and try to bring about change. The Russian people, on the other hand, are portrayed as inexplicably passive objects, derived of agency, rendering the American people all the more active, reasonable and individually differentiated.

A similar difference can also be noted when the textbooks set out to explain the motives behind the actions of American and Soviet leaders during the Cold War. The USSR appears not only as the most active party in the escalation of the conflict; the motives of the Soviet leaders are rarely 
given any rational explanation. Apart from Stalin's hunger for more power, the reader is merely given declarative examples of how Soviet troops quash freedom-longing peoples' efforts towards democracy. In comparison, the actions of the USA appear considerably more rational in the sense that they act according to economic incentives and a logical ambition to limit the ideological influence of the USSR in other parts of the world.

Drawing on Arendt $(1982,1998)$ and asking to what extent the readers of these textbooks are given the opportunity to relate to these two historical actors, we can ascertain that whenever it comes to the Russians the voice of the textbook narrative is conspicuously often that of the distant beholder or tourist. The challenges that Russian people face seem to have very little in common with the situations 'we' (Swedish students) usually face. Generally speaking and beyond the particular case of the Russians, the distance is greatest when the textbook narratives implicitly indicate a moral assessment. The reader is always invited to identify with the victims of Soviet or American deeds. On the contrary, the acts of the perpetrator are rarely ever contextualised.

The perspective of the victim can in many ways be ethically appealing in a school context. The risk of this approach is, however, that it may promote a use of history where we from the vantage point of our safe contemporary world, like judging spectators, contemplate historical wrongdoings. We make no attempts at 'visiting', and the history of human atrocities thereby becomes a mere declarative description of someone else's morally condemnable acts. In the worst case scenario, the school subject of history may in this way become an activity that obstructs our younger generations from raising critical existential questions about what it means to be human.

\section{Notes}

1. 'Jämfört med Tyskland eller Frankrike var Ryssland outvecklat. Nio av tio människor bodde i byar på landet och levde av jordbruk. Tre av fyra vuxna var analfabeter. Missväxt och hunger var vanliga. [...] Tillsammans med höns, kor och svin försökte de [ryska bönderna] uthärda vinterkylan, när snön drev in genom tunna väggar och den kalla fukten steg från jordgolven' (Levande historia, 320). 
2. '[Bönderna] [...] blev undernärda, kraftlösa och förtvivlade' (PULS, 192).

3. '[...] mot dem som tog utan att ge något tillbaka' (Levande historia, 322).

4. 'Det sägs att "de röda" sköt alla som inte hade valkar i händerna' under inbördeskriget (PULS, 197).

5. 'Han [Lenin] lät sina soldater stövla in och stänga det nyvalda riksdagen med våld. Politiker som folket valt kastades ut, och Lenin blev Rysslands diktator' (SO.S., 248).

6. '[Stalin]'s sjukligt misstänksam', 'likt Hitler slug envåldshärskare' (PULS, 201).

7. '[Stalin] [...] lyckades efter en rad fula knep'.

8. 'De [det kommunistiska Sovjetunionen och det nazistiska Tyskland] ville få varenda människa att tänka på ett helt nytt sätt. Alla som inte helt och hållet ville stödja partiet skulle ses som fiender, utan rätt att leva' (SO.S., 257).

9. '[...] i den hemliga polisens tortyrkammare drevs oskylda människor att peka ut sina bästa vänner som förrädare och fiender till Sovjetunionen. Barn angav sina föräldrar, till och med Stalins släktingar greps' (SO.S., 260).

10. 'I lägren blandades politiska fångar med grovt kriminella. Fångar kunde våldtas, mördas arbeta sig till döds eller dö av hunger och sjukdomar. Det krävdes såväl styrka som list och tur för att överleva [...] Känslan av att ingen, absolut ingen, gick säker skapade en enorm misstänksamhet och rädsla som genomsyrade hela samhället. Vem som helst kunde vara angivare. Det var lätt att ange någon man ogillade, en granne vars rum man ville åt - manga familjer tvingades nämligen dela lägenhet - en svartsjukerival eller en flicka som vägrat ha sex' (Levande historia, 331).

11. 'Sovjet kunde tillverka kärnvapen som hotade hela världen, men inte tillräckligt med mat, kläder och bostäder å sitt eget folk. Det fanns gott om naturtillgångar i Sovjetunionen: guld, olja, kol, järn och mycket annat. Kommunisterna skövlade naturen för att komma åt dessa rikedomar. Så fick de råd att utrusta världens starkaste armé. Men stora delar av landet förgiftades av miljöförstöring' (SO.S., 110).

12. 'Ingen vågade eller ville ta egna initiativ' (PULS, 306).

13. 'De nya ledarna som kom till makten under 1950- och 60-talen bestämde att det skulle produceras mer mat, kläder, bostäder, bilar och tv-apparater. Sånt som människor behövde. Då visade sig en av Sovjetunionen 
stora svagheter: För vanliga människor var det förbjudet att äga företag och försöka bli rik. I Sovjetunionen var det staten som ägde alla företag. Och det spelade ingen roll om ett företag gick dåligt, staten betalade arbetarnas löner ändå. Därför brydde sig många anställda inte om att anstränga sig. Det var vanligt att folk var fulla på jobbet, inte gick dit alls. När staten ägde företagen fanns det många som inte kände ansvar. Folk stal varor och sålde dem. Fabrikerna och jordbruken fungerade allt sämre ju längre tiden gick. [...] De som vågade klaga dömdes till straffarbete, eller låstes in på mentalsjukhus. Fast de som arbetade åt partiet hade det bra. De kunde få resa utomlands, och handla i speciella butiker med utländska varor. Där fanns allt som vanligt folk saknade' (SO.S., 374-375).

14. '[...] ofta gick bondens sista pengar till vodka' (PULS, 192).

15. '[...] humorn och vodkan var folket tröst och säkerhetsventil' (PULS, 306).

16. '[...] i affärerna fanns det nästan ingenting att köpa, förutom vodka' (SO.S., 259).

17. [I stora delar av Östeuropa] 'Där hade man aldrig fătt lära sig demokrati i västerländsk mening' (PULS, 284).

18. 'År 1948 blockerade Sovjetunionen västmakternas delar av Berlin för att försöka svälta ut området och sedan ta över. Västmakterna - USA, Storbritannien och Frankrike - svarade med att låta en ström av plan, en luftbro, flyga in livsmedel och andra varor. Stalin måste vika sig och blockaden hävdes efter elva månader. $\mathrm{Nu}$ var förhållandet mellan Sovjetunionen och USA bottenfruset. Konflikten blev genom den amerikanske journalisten Walter Lippman känd som Det kalla kriget' (Levande historia, 378).

19. 'Stalin ville göra Sovjet till världens starkaste land' (SO.S., 10).

20. 'Efter 1948 styrdes nästan hela Östeuropa från Moskva "gränserna bevakades stenhårt", de som försökte fly stoppades eller sköts i flykten' (PULS, 284).

21. '[...] sedan Sovjetunionen hade infört kommunismen i Östeuropa började det kalla kriget'.

22. '[...] varje gång östeuropeiska folkens frihetsdrömmar av sovjetiska stridsvagnar' (SO.S., 378).

23. ' 1989 blev frihetens och de demokratiska revolutionernas år för Östeuropa' (SO.S., 379). 
24. 'Att kommunistpolitikerna lyckades behålla makten berodde på att det inte fanns tillräckligt många människor i dessa länder som visste hur demokrati fungerade' (SO.S., 379).

'Ofta var de bönder, fattiga men arbetsamma som Karls Oskar och Kristina'.

'Så föddes USA', '[...] alla människor är skapade jämlika', '[...] all makt utgå från folket, alla lagar ska godkännas av folkets representanter'.

'Ofta var de bönder, fattiga men arbetsamma som Karls Oskar och Kristina'.

'Så föddes USA', '[...] alla människor är skapade jämlika', '[...] all makt utgå från folket, alla lagar ska godkännas av folkets representanter'.

'USA blev det land där fabrikerna tillverkade mest varor i hela världen. Massor av människor fick arbete och tjänade pengar'.

'Var verkligen USA framtidslandet för alla?' (Utkik, 167).

'Tyckte alla i USA att det var det glada 20-talet?' (Utkik, 229).

'[...] ur krigets ruiner växer ett nytt Västeuropa fram, rikare än någonsin' (SO.S., 304).

År 1947 kom USAs regering med ett hjälpprogram för det krigshärjade Europa. Den så kallade Marshallhjälpen innebar att Västeuropas länder fick nästan 13 miljarder dollar av USA. Amerikanerna ville få fart på Europas ekonomi, så att européerna skulle få råd att köpa saker från USA. Dessutom var amerikanerna rädda för att fattigdomen skulle göra att västeuropéerna började rösta på kommunistiska partier' (SO.S., 304).

'Ekonomiska intressen står över ideal om demokratins befriare', 'skylt på hot från kommunismen’ (PULS, 329).

'Stora amerikanska företag äger mycket i Sydamerika' (SO.S., 365).

'[...] även om de var diktatorer. I land efter land togs makten över av USA-stödda militärregimer' (SO.S., 365).

'USAs mjölkko'.

'Den 6 augusti sprängdes en atombomb över den japanska staden Hiroshima. 80000 dödades omedelbart, 70000 skadades och hela staden lades i aska. Tre dagar senare sprängdes ytterligare en atombomb över staden Nagasaki. Det är första och hitintills enda gången atombomber har använts i krig. Japan kapitulerade utan villkor. Andra världskriget var slut' (Levande Historia, 365). 
'Kvart i nio på morgonen den 6 augusti 1945 släpptes den första atombomben över den japanska staden Hiroshima. På några minuter dog 80000 människor. Tre dagar senare släpptes en ännu kraftigare bomb över staden Nagasaki. Dagen därpå var Japan berett att ge upp. Det andra världskriget var slut' (SO.S., 283).

[Vietnamkriget] '[...] förstörde mycket av USAs goda rykte i världen' [...] [det amerikanska folket tvingades inse att det egna landet] 'hamnat på den "onda" sidan' (SO.S., 342).

'För många unga människor blev USAs krig i Vietnam en symbol för hur den rika världen försökte krossa ett fattigt folk som bara ville leva på sitt eget sätt' (SO.S., 311).

'[...] förbättrades den amerikanska ekonomin' [och de svarta lyckades utbilda sig och kunde] '[...] arbeta sig upp i samhället'.

25. 'Ofta var de bönder, fattiga men arbetsamma som Karls Oskar och Kristina'.

26. 'Så föddes USA', '[... ] alla människor är skapade jämlika', '[...] all makt utgå från folket, alla lagar ska godkännas av folkets representanter'.

27. 'USA blev det land där fabrikerna tillverkade mest varor i hela världen. Massor av människor fick arbete och tjänade pengar'.

28. 'Var verkligen USA framtidslandet för alla?' (Utkik, 167).

29. 'Tyckte alla i USA att det var det glada 20-talet?' (Utkik, 229).

30. 'en hysterisk häxjakt' (PULS, 298).

31. '[...] ur krigets ruiner växer ett nytt Västeuropa fram, rikare än någonsin' (SO.S., 304).

32. ‘̊̊r 1947 kom USAs regering med ett hjälpprogram för det krigshärjade Europa. Den så kallade Marshallhjälpen innebar att Västeuropas länder fick nästan 13 miljarder dollar av USA. Amerikanerna ville få fart på Europas ekonomi, så att européerna skulle få råd att köpa saker från USA. Dessutom var amerikanerna rädda för att fattigdomen skulle göra att västeuropéerna började rösta på kommunistiska partier' (SO.S., 304).

33. 'Ekonomiska intressen står över ideal om demokratins befriare', 'skylt på hot från kommunismen" (PULS, 329).

34. 'Stora amerikanska företag äger mycket i Sydamerika' (SO.S., 365).

35. '[...] även om de var diktatorer. I land efter land togs makten över av USA-stödda militärregimer' (SO.S., 365).

36. 'USAs mjölkko'.

37. 'Den 6 augusti sprängdes en atombomb över den japanska staden Hiroshima. 80000 dödades omedelbart, 70000 skadades och hela staden 
lades i aska. Tre dagar senare sprängdes ytterligare en atombomb över staden Nagasaki. Det är första och hitintills enda gången atombomber har använts i krig. Japan kapitulerade utan villkor. Andra världskriget var slut' (Levande historia, 365).

38. [Vietnamkriget] ' ...förstörde mycket av USAs goda rykte i världen [...] [det amerikanska folket tvingades inse att det egna landet] hamnat på den “onda” sidan' (SO.S., 342).

39. 'Eftersom man hade svårt att skilja på "fiender" och "vänner” brände man ibland byar på måfå’ (Utkik, 271).

40. 'För många unga människor blev USAs krig i Vietnam en symbol för hur den rika världen försökte krossa ett fattigt folk som bara ville leva på sitt eget sätt' (SO.S., 311).

41. '[...] förbättrades den amerikanska ekonomin [och de svarta lyckades utbilda sig och kunde]' [...] arbeta sig upp i samhället'.

\section{Bibliography}

\section{List of Textbooks Cited}

Almgren, Bengt, David Isaksson, Berndt Tallerud and Hans Thorbjörnsson. 2016. Prio: Historia 9. Stockholm: Sanoma utbildning AB.

Hildingson, Kai and Lars Hildingson. 2012. Levande historia 9. Stockholm: Natur \& Kultur.

Ivansson, Elisabeth and Mattias Tordai. 2015. SO-S: Historia Ämnesboken. Stockholm: Liber.

Körner, Göran and Lars Lagheim. 2009. PULS: Grundbok Historia. Stockholm: Natur \& Kultur.

Nilsson, Erik, Hans Olofsson and Rolf Uppström. 2015. Utkik: Hi Historia 7-9. Malmö: Gleerups.

\section{References}

Andersson, Nils. 2010. 'Intercultural Education and the Representation of the Other in History Textbooks'. In Opening the Mind or Drawing Boundaries? History Texts in Nordic Schools, edited by Thorsteinn Helgason and Simone Lässig, 33-60. Göttingen: V\&R unipress. 
Arendt, Hannah. 1982. Lectures on Kant's Political Philosophy. Chicago: The University of Chicago Press.

Arendt, Hannah. 1998. Människans villkor: Vita activa. Göteborg: Daidalos.

Blake, C. 1998. 'Empathy: A Response to Foster and Eager'. International Journal of Social Education 13: 25-31.

Danielsson Malmros, Ingmarie. 2012. Det var en gång ett land: Berättelser om svenskhet $i$ historieläroböcker och elevers föreställningsvärldar. Diss. Lund: University of Lund, 2012.

Disch, Lisa J. 1994. Hannah Arendt and the Limits of Philosophy. New York: Cornell University Press.

Disch, Lisa J. 1997. "Please Sit Down, but Don't Make Yourself at Home”: Arendtian "Visting" and the Prefigurative Politics' Hanna Arendt and The Meaning of Politics, edited by Craig Calhoun and John McGowan. Minneapolis: University of Minneapolis Press.

Gustafsson, Jörgen. 2017. Historielärobokens föreställningar: Påbjuden identifikation och genreförändring i den obligatoriska skolan 1870-2000. Diss. Uppsala: University of Uppsala.

Holmén, Janne. 2006. Den politiska läroboken: Bilden av USA och Sovjetunionen i norska, svenska och finländska läroböcker under kalla kriget, Diss. Uppsala: University of Uppsala.

Lévesque, Stephane. 2008. Thinking Historically: Educating Students for the Twenty-first Century. Toronto: Buffalo.

Loftsdóttir, Kristín. 2010. 'Deconstructing the Eurocentric Perspective: Studying "Us" and the "Other" in History Books'. In Opening the Mind or Drawing Boundaries? History Texts in Nordic Schools, edited by Thorsteinn Helgason and Simone Lässig, 21-32. Göttingen: V\&R unipress.

Lozic, Vanja. 2010. I historiekanons skugga: Historieämne och identifikationsformering i 2000-talets mångkulturella samhälle. Diss., Malmö: University of Lund, 2010.

Nordgren, Kenneth. 2006. Vems är historien: Historia som medvetande, kultur och handling $i$ det mångkulturella Sverige. Diss. Umeå: Umeå Universitet.

Persson, Anders. 2016. 'Mormor, oönskade tyskar och en hänsynslös dansk: Några reflektioner om identifikation och mening, efter en kritisk läsning av en nyutgiven lärobok i historia för den svenska grundskolans mellanår’. In Kulturell reproduktion i skola och nation: En vänbok till Lars Petterson, edited by Urban Claesson and Dick Åhman, 251-268. Möklinta: Gidlunds.

Persson, Anders and Robert Thorp. 2017. 'Historieundervisningens existentialiserande potential'. Nordidactica 2 . 
Persson, Anders. 2017. Lärartillvaro och historieundervisning: Innebörder av ett nytt uppdrag i de mätbara resultatens tid. [History teaching in the age of performativity: Swedish upper primary school teachers' experiences of a new curriculum]. Diss. 2017. Umeå: University of Umeå.

Retz, Tyson. 2015. 'A Moderate Hermeneutical Approach to Empathy in History Education', Educational Philosophy and Theory 47, no. 3: 214-226.

Spjut, Lina. 2014. Den envise bonden och Nordens fransmän: Svensk och finsk etnicitet samt nationell historieskrivning $i$ svenska och finlandssvenska läroböcker 1866-1939. Lic-uppsats. Umeå: Umeå universitet, 2014.

Spjut, Lina. 2018. Att (ut)bilda ett folk: Nationell och etnisk gemenskap i Sveriges och Finlands svenskspråkiga läroböcker för folk- och grundskolan åren 18662016. Diss. Örebro, Örebro universitet.

Zander, Ulf. 1998. 'Att legitimera och bli legitimerat: Historieämnet förr och nu i Sverige och annorstädes'. In Historiedidaktiska utmaningar, edited by Hans Albin Larsson, 32-68. Jönköping: Jönköping university press.

Open Access This chapter is licensed under the terms of the Creative Commons Attribution 4.0 International License (http://creativecommons.org/licenses/ by/4.0/), which permits use, sharing, adaptation, distribution and reproduction in any medium or format, as long as you give appropriate credit to the original author(s) and the source, provide a link to the Creative Commons licence and indicate if changes were made.

The images or other third party material in this chapter are included in the chapter's Creative Commons licence, unless indicated otherwise in a credit line to the material. If material is not included in the chapter's Creative Commons licence and your intended use is not permitted by statutory regulation or exceeds the permitted use, you will need to obtain permission directly from the copyright holder.

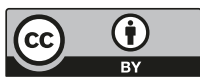

